\title{
Ownership Structure and Firm Performance: The Role of Managerial and Institutional Ownership-Evidence from the UK
}

\author{
Bernard Ogabo' , Godspower Ogar², Tasha Nuipoko \\ ${ }^{1}$ Coventry University, Coventry, UK \\ ${ }^{2}$ Department of Accounting, Faculty of Management Sciences, University of Calabar, Calabar, Nigeria \\ ${ }^{3}$ University of Dundee, Dundee, UK \\ Email: bernardogabo@yahoo.co.uk, ogar.godspower@unical.edu.ng, go2taasha@yahoo.com
}

How to cite this paper: Ogabo, B., Ogar, G. and Nuipoko, T. (2021). Ownership Structure and Firm Performance: The Role of Managerial and Institutional OwnershipEvidence from the UK. American Journal of Industrial and Business Management, 11, 859-886.

https://doi.org/10.4236/ajibm.2021.117053

Received: June 26, 2021

Accepted: July 27, 2021

Published: July 30, 2021

Copyright $\odot 2021$ by author(s) and Scientific Research Publishing Inc. This work is licensed under the Creative Commons Attribution International License (CC BY 4.0).

http://creativecommons.org/licenses/by/4.0/

\begin{abstract}
The separation between ownership and control has been identified as the main cause of the agency problem, resulting in a disparity between the interests of the agents and those of the principals, and consequently, there is an impact on performance. Corporate governance mechanisms are the main ways of resolving the agency problem at all levels. This study examines the impact of ownership structure on firm performance of the United Kingdom's FTSE 350 companies from the 2008-2018 fiscal years. Specifically, the impact of managerial and institutional ownership on return on asset, return on equity, and Tobin's $\mathrm{Q}$ as measures of performance were investigated. A panel data set of 48 companies with 432 observations was analysed using descriptive statistics, correlation matrix, and regression analysis. The results revealed that there is a significant positive impact of managerial ownership on firm performance without any entrenchment effect at managerial ownership above $5 \%$. The regression results showed that the control variables of the percentage of independent directors on the board increase firms' performance, while the percentage of women on the board as a control variable decreases firms' performance. These results are succinct contributions to the extant literature on the impact of ownership structure and performance.
\end{abstract}

\section{Keywords}

Corporate Governance, Agency Problem, Managerial Ownership, Institutional Ownership, Entrenchment Hypothesis, Endogeneity

\section{Introduction}

Finding an answer to the role of the governance tool of ownership structure on 
firms' performance has been a subject of several studies, but the results have been inconclusive. This study investigates the impact of ownership structure on firms' performance and aims to determine if firms' performance rather influences ownership structure. The term Corporate Governance which involves the overall process employed by entities to ensure the well-being of the organizations has become a subject of intense study since the series of fraudulent corporate practices and consequent failures witnessed in the early $21^{\text {st }}$ century. While this concept may have been entrenched into some organizational culture since the 18th-century industrialization waves, it never became a popular study interest until large-scale corporate failures such as Enron, WorldCom, Adelphia, etc. occurred in the early 2000s. However, a related concept like the agency theory became prominent in finance literature with the separation of ownership and control of firms in the early $19^{\text {th }}$ century (Grant, 2003).

The Organization for Economic Corporation and Development (OECD) defined Corporate Governance as "how organizations are directed and controlled" and this indicates the factors that determine firms' performances (Babatunde \& Olaniran, 2009).

The mechanisms of Corporate Governance are largely categorized into two: "Internal and External governance mechanisms". Internal governance methods, for instance, involve ensuring that there is Chief Executive duality, allotment of ownership to managers, the appropriate mix of Executive and non-Executive directors, appropriate Board size, etc. External governance processes, on the other hand, are mechanisms that are not firm-specific but affect the entire market or industry in which a company operates like monitoring from regulatory authorities and using equity performance in facilitating take-overs bids; a concept known as "market for corporate control" (Weir et al., 2001; Denis \& McConnel, 2003; Gillan, 2006; Babatunde \& Olaniran, 2009). This study is, however, focused on testing the impact of the selected governance mechanisms of Managerial and Institutional ownership on firms' performance.

Berle and Means (1932) note that there is a converse association between diffuse ownership structure and corporate performance which is caused by the modern corporate scenario where a firm's ownership is separate from its control giving room for the management to employ several self-gratifying tactics which are a disadvantage to shareholders. Shareholders who buy financial assets in form of shares from a company often do so with a tiny portion of their wealth and could also have their portfolio sufficiently diversified, which may give them a nonchalant attitude towards risks. Managers on the other hand, who invest their lives and intellect in the running of the business have higher risk exposures than the owners and therefore, seem to be prone to self-protecting decisions and actions which are inimical to the survival of the firm. Also, factors like the desire to run big businesses or trying to get oneself insulated against removal by firms' owners push managers into engaging in actions that are against business growth, rightly identified by Jensen and Meckling (1976) as agency conflict. 
To curb the incidences of the managerial exhibition of conflict of interest, shareholders incur bonding cost (allotment of shares to managers, bonuses and perquisites), monitoring costs (separation of the office of the Chairman from that of the CEO, having Independent Non-Executive directors, using the influence of large shareholders, using the influence of institutional shareholders) and, bearing the final losses (when and if the company goes bankrupt). Managerial ownership, for instance, is a tool designed to make the managers share in the vision of the shareholders while bloc shareholding and shares owned by corporate bodies are mechanisms believed to be effective in exerting monitoring influence on the managers.

The United Kingdom having a diffuse ownership structure and high institutional corporate subscribers offer a great platform for the study of the effect of these kinds of ownership structures on firms' performances. Firstly, this study seeks to establish or disprove the fact that dispersed ownership arrangement among UK companies has given rise to agency costs and managerial ownership is a solution in this regard.

To achieve this, this study did not study the impact of agency costs on firms' performance but sought to find out if managerial ownership has any impact on firms' performance which will either confirm the "alignment of interest hypothesis" of Jensen \& Meckling (1976) or the entrenchment hypotheses of Shleifer \& Vishny (1989). Second, this study examines the role institutional owners' play in impacting firms' performance. For the United Kingdom, the institutional ownership structure is an interesting variable of study because, on average, each UK FTSE 350 company has an institutional shareholding of more than $50 \%$, implying that this class of owners will tend to exert more influence on the activities of management, therefore, impacting performance. Also, institutional investors are often under pressure to give returns to their subscribers and therefore will be more active in ensuring that their investee companies are charting the right course. Another issue worthy of note is that the dispersed ownership structure arrangement in the UK will mean that each unit holder of shares will find it too expensive to try and police managers into acting properly (Maug, 1998; Grossman \& Hart; 1980; Shleifer \& Vishny, 1986) therefore leaving agency costs to fester and their impact if any. Therefore, ownership concentration has not been considered in this study, only Managerial and Institutional ownership is considered.

Further, ownership concentration seen in the analysis of this study is a dummy variable to test the impact of managerial ownership above $5 \%$. This was an important construct because managerial ownership as observed from the sample studied was below $5 \%$ in almost all the companies. From previous studies, share ownership of $5 \%$ and above among the UK publicly listed companies is an ownership concentration. Therefore, a manager owning more than $5 \%$ might as well be able to wield the influence that might be like the "entrenchment hypothesis". So far, this is the first study to view managerial ownership in the UK 
in this light. This is the first time that entrenchment hypothesis has been tested in the UK using this approach. Another issue considered in this study is the possibility of a simultaneous impact between performance and ownership structure, the concept of "endogeneity".

The UK stock exchange offers a veritable platform to investigate the issue of diffuseness of ownership and the incidence of agency and managerial ownership. The FTSE 350 index represents the largest 350 UK companies and therefore offers all the characteristics needed to investigate both Managerial and Institutional ownership. The fundamental motivation for this study is to determine the impact of ownership structure on firm performance of UK FTSE 350 companies for the period 2008-2018; with specific objectives namely, to examine the impact of managerial ownership on firm performance, to further determine the impact of institutional ownership on firm performance. Also, to establish if there is a two-way influence between ownership structure and firm performance, and finally to determine if managerial ownership above $5 \%$ gives rise to managerial entrenchment.

This article is structured as follows: the introduction above provides a broad overview of ownership structure and firm performance. It also provided the major motivations and objectives for this study. The second part delves into the literature review. Specifically, it provides the theoretical background and highlighted extant and relevant literature on managerial ownership, institutional ownership, and endogeneity of performance and ownership structure. The third section provides an overview of the data source, the research methodology, model specification, and the definition of variables. The fourth section shows the empirical analysis, hypothesis testing and the interpretation/discussion of results. The last section focuses on the limitation faced and provides recommendations.

\section{Literature Review}

\subsection{Theoretical Background}

The fundamental Corporate Governance theory underpinning ownership structure is the agency theory. Smith (1776) was the first to show a glimpse of what an agency conflict is when he suggested that managers would be unwilling to give the same level of vigilance they give when they are running a business owned by them. The agency theory was, however, popularized by Jensen and Meckling (1976) based on the novel work of Berle and Means (1932) on the theory of the modern corporation. Berle and Means highlighted the fact that modern firm owners buy shares and own corporations and become shareholders but hire managers to run the business on their behalf; hence, there is a separation between ownership and control. This scenario creates a contractual relationship between the owners and the managers. Jensen and Meckling hold that the contract between managers and shareholders is that of the principal and an agent. Therefore, the principals hire agents to carry on the transactions of the firm on 
their behalf.

A conflict of interest is, however, prevalent because of the separation of ownership and control (Jensen \& Meckling, 1976). The self-interest action of managers is evident in them engaging in actions that produce rewards to them rather than shareholders. Managers may be engaged in business expansion at the expense of payments of dividends because some managers are interested in managing large businesses even if expanding the business and diversifying makes such businesses less profitable. Also, most managers are obsessed with earning bonuses, increased pay and other benefits; hence, they may adopt many strategies to improve earnings and meet up with performance measures that qualify them for these benefits (Fitza \& Tihanyi, 2017). Managers also have both the ability and capacity to undertake inefficient investments because they are more expose to inside information about the company than the shareholders. Managers' exhibition of conflict of interest comes at costs to the shareholders (Foss et al., 2020). Shareholders adopt several methods like issuing shares to managers to align their interest with that of the shareholders, monitoring their actions with non-executive directors, using the influence of large shareholders in concentrated ownership to moderate the excesses of the managers, and ultimately bearing residual losses when and if the company eventually folds up. Issuing shares to managers help to unify their interests with those of the firms' owners (Jensen \& Meckling, 1976; Shleifer \& Vishny, 1997; Fama \& Jensen, 1983) but might result in managerial entrenchment a situation where the shareholding of managers gives them so much influence until they are insulated against other monitoring activities by the shareholders (Shleifer \& Vishny, 1989).

Equally, using concentrated ownership to moderate managers may reduce their level of conflict of interest but introduces another problem of expropriation of minority shareholders. Large shareholders block the free-rider problem when it comes to shareholders' activism but end up oppressing the minority shareholders, which brings another conflict of interest between majority and minority shareholders. Several empirical types of research have documented the costs of separation of ownership and control like self-interest actions involving Capital structure (Leland, 1998), dividend policy decision (Fenn \& Liang, 2001), Executive remuneration (Hartzell \& Starks, 2003). Other areas of conflict of interest actions of management bother on Mergers and acquisitions, earnings management, and the issue of shares as documented by (Garcia-Meca \& Sanchez-Ballesta, 2009; Masulis, Wang, \& Xie, 2009; Barclay, Holderness, \& Sheehan, 2007) respectively.

On the contrary, agency cost is thought to be minimal or minimize in private firms, especially in an owner-managed firm or higher ownership concentration. There are studies, however, which have documented cases of agency conflict in private firms. For instance, Hope et al. (2012) documented that selection of auditors in private is affected by managers' self-interest. O'Callaghan, Ashton and Hodgkinson, 2018 found evidence that private firms engage in earnings man- 
agement when their profits are low; this is more so if it is an income-enhancing discretionary accrual and it varies "non-linearly with managerial ownership". Also, Fleming, Heany and Mc Cosker (2005) found that there is a negative relationship between agency cost and managerial ownership, which is indicative of misaligned incentives in private entities that impact corporate performance.

\subsection{Managerial Ownership and Firm Performance}

Managerial ownership refers to the percentage of shares owned by the managers in a corporation. Proxies for Managerial ownership have either been the number of shares held by the Executive Directors (ED) or the number of shares held by the Managing Director (MD). Managerial ownership can also be called insider shares percentage. Jensen and Meckling (1976); Morck et al. (1988); McConnell \& Servaes (1995); Balatbat et al. (2004) and Bolton (2012) all share a consensus on the opinion that shares held by managers help to align their interests with that of the shareholders, or more broadly speaking managerial shares are internal corporate governance mechanism. The above scholarship is in agreement over the significant impact of shares ownership by managers on firms' performance indices. When managerial shareholding increase, the propensity that managers would bear the costs of diverting the firm's resources becomes higher, and this becomes a disincentive to managers to the expropriation of the firm's resources.

There is a collection of mixed findings when it comes to the impact of managerial ownership on corporate performance. For instance, Jensen and Meckling (1976) suggest that managerial ownership has a positive impact on performance since there is interest alignment through insider ownership. Similarly, Balatbat et al. (2004); Agrawal \& Knoeber (1996); Chang (2003) and Morck et al. (1988) reported a positive relationship between managerial ownership and corporate performance. Also, Mehran (1995) found that there is a positive association between managerial share ownership and the performance of American manufacturing firms. Keasey et al. (1994) study found that in private firms, a curvilinear relationship exists between managerial ownership and firm performance. Specifically, the Return on Asset increases with managerial share ownership to a maximum of 68.2 ownership percentage after which it then decreases as shares owned by the agents' approach 100\%. Shan (2019) in his study of 9302 Australian listed firms showed that the "convergence-of-interest" hypothesis increases performance when managerial ownership is between $0 \%-20 \%$ while the "entrenchment hypothesis effect decreases performance when management ownership of shares is between of $20 \%-50 \%$ holding level. Also, Iturralde et al. (2011) found that managerial ownership increases corporate performance when managerial shares are between $0 \%-35 \%$, as ownership increases from $35 \%-70 \%$, firm performance decreases. In the same vein, Morck et al. (1988) found that firms' performance rises as insider's ownership rises from $0 \%-5 \%$, declines as the ownership moves towards $25 \%$ and starts rising again but slowly when ma- 
nagerial ownership grows beyond $25 \%$.

In contrast, some studies have found a negative impact of managerial or insider ownership on a firm's performance. For example, Jensen and Murphy (1990), Slovin and Sushka (1993), Boyle et al. (1998), and Agrawal and Mandelker (1990) all reported a negative relationship between managerial ownership and corporate performance. Their findings may have offered credence to the entrenchment hypothesis which posits that as managerial ownership increases, managers become entrenched and this decreases firm/corporate value (Fama \& Jensen 1983; Morck et al., 1988). Demsetz (1983) also agreed that corporate performance declines as managerial ownership rises. Studies like those of Demsetz and Villalonga (2001) and Loderer and Martin (1997) conclude that managerial ownership has no impact on corporate performance. Instead, firm performance is implicitly an explanatory variable that has an impact on or influences managerial ownership. Thus, from the preceding debates, we hypothesize that:

H1: Managerial ownership does not have a significant impact on firm performance.

\subsection{Institutional Ownership and Firm Performance}

Institutional ownership represents share ownership by corporate organizations in another entity. Studying how institutional ownership influences or affects firms' performance becomes vital as they seem to be actively involved in influencing corporate decisions and consequently, performance. Institutional investors influence corporate decisions in areas such as corporate control and governance practices, improving industry capacity and firm's investment competitiveness (Fung \& Tsai, 2012). Large investors have more resources and incentives to monitor businesses this incentive is because institutional investors have large holdings and may find it less easy to liquidate their investments hence have the higher drive to monitor corporate performance (Shleifer \& Vishny, 1986; Grossman \& Hart, 1980; Maug, 1998). When shares held by institutional investors are less, they could quickly liquidate their investments and move on.

There is a plethora of research on the impact of institutional ownership on corporate performance that yielded mixed findings. While some researchers treated institutional ownership as a variable having a homogenous impact, others believe that institutional ownership has a heterogeneous impact as some groups of institutional owners exert more influence on the corporation than the others (Brickley et al., 1988; Almazan et al., 2005; Chen et al., 2011). Institutional investors like banks and insurance companies suffer from self-interest threats and are less likely to monitor the activities of the companies that they invest. These are called pressure-sensitive institutional investors. Pressure, insensitive institutional investors, on the other hand, are companies like investment companies that have no self-interest in the activities of a company are more likely to monitor the activities of the organization. Studies carried out by Almazan et al. (2005), and Chen et al. (2011) showed that shareholdings by pressure insensitive 
institutional investors result in a greater discipline over executive compensation and acquisition decisions respectively. This study, however, and the literature covered will consider the overall impact of institutional ownership on corporate performance and not the respective impact of the different types of institutional ownership. Gillan and Starks (2000) showed that Corporate Governance processes initiated or sponsored by institutional investors receive more support than those sponsored by individuals or smaller shareholders.

Research into the impact of monitoring activities of institutional investors by McConnell and Servaes (1995), Nesbitt (1994), Smith (1776) and Del Guercio and Hawkins (1999) show that corporate monitoring by Institutional shareholders' pressures managers into focusing more on activities or investments that enhance corporate performance rather than managers pursuing their self-interest. Therefore, there is a positive effect of institutional ownership on corporate performance. Cornett et al. (2007) find that there is a significant relationship between a firm's institutional investors' percentage and corporate performance which is highly valid for classes of institutional investors that are not able to have a business relationship with the firms. Li et al. (2006) studies show that Institutional ownership does not have a direct but an indirect impact on corporate performance such as profitability. They, however, found a significant direct impact on other corporate governance measures such as diversity, CEO duality, Board Composition and Ownership concentration. Hartzell and Starks (2003) find that as institutional shareholding increases, executive compensation decreases and pay-for-performance increases with institutional shareholding.

Elyasiani and Jia (2010) studied institutional ownership distribution and stability and how they impact corporate performance. The result showed that there is a strong relationship between institutional ownership stability and corporate performance. Fung \& Tsai (2012), La Porta et al. (2000), and Ameer et al. (2010) all provide evidence that institutional ownership positively impacts corporate performance. They believe that this positive impact is possible through monitoring activities and expert advice afforded to firms by institutional investors. On the contrary, Agrawal and Knoeber (1996), Karpoff et al. (1996), Duggal and Miller (1999) and Faccio and Lasfer (2000) find no significant relationship between Institutional investors share ownership and corporate performance. Institutional investor stock ownership on firm performance is still unclear. Therefore, we hypothesize:

H2: Institutional ownership does not have any significant impact on firm performance.

\subsection{Endogeneity, Ownership Structure and Firm Performance}

Many studies since the post-Berle and Means (1932) era have traditionally treated ownership structure as an exogenous variable influencing corporate performance, but many studies have ventured of late to look at ownership structure as a two-way outcome of shareholders' activities known as "endogeneity". Dem- 
setz (1983) was the first to observe the bi-directional impact of ownership structure when he opined that the ownership structure is endogenously determined through the profit maximization activities of shareholders. When owners of publicly listed companies decide to sell their shares, they are consciously changing the ownership structure which may be the consequence of their fate or otherwise in the performance of the stock, therefore, changes in ownership structure should not be influencing corporate performance (Demsetz \& Villalonga, 2001). Demsetz and Lehn (1985) found no significant relationship between ownership concentration and corporate performance when they controlled for firm's risk level, regulations and industry-specific factors because these seem to be the main determinants of ownership concentration. Kole (1996) found that managerial ownership is endogenous to compensation practices; managers will only take equity compensation if they expect their firms to perform well. The following studies also looked at ownership structure as the endogenous outcome that shows the influence of shareholders and their buying and selling of share activities (Morck et al., 1988; Loderer \& Martin, 1997) while the studies of Foroughi and Fooladi (2011) controlled for the determinants of ownership on performance. Loderer and Martin (1997) found that board structure was a concept studied, is influenced by the past performance of the firm.

H3: There is no bi-directional impact between ownership structure and firm performance

\section{Methods}

\subsection{Data Collection}

We obtained data for this research from the Bloomberg L.P terminal. The Bloomberg trading terminal and statistical software is a very robust platform that contains information on the trading equity and other accounting information on all listed firms in developed and emerging markets. Historical information on share prices, income statements, statements of financial position, cash flows can be obtained for companies for as long as 20 - 25 years back if needed. Independent variable proxies for corporate governance measures like board Size, firm size, firm age, percentage of women on the board, percentage of insider ownership, percentage and number of institutional shares held, leverage and other key measures are part of the variables of interest for this research are extractable from the Bloomberg terminal. Specifically, the data studied covered the 2008-2018 fiscal years. The variables for managerial ownership, institutional ownership, ownership concentration, percentage of women on the board, percentage of independent directors on the board, board size, return on asset, return on capital employed and Tobin's Q ratio were obtained from the database for further analysis.

\subsection{Sample and Sampling Method}

The initial sample of this study consists of all companies listed on the floor of the 
London Stock Exchange classified as Financial Times Stock Exchange Index 350 (FTSE 350) companies. As recorded by the Bloomberg terminal, there are 351 FTSE 350 companies. Out of these, 48 were randomly selected from 295 active companies and have been analyzed to achieve the research objectives. 56 companies were eliminated from the list because they are in liquidation, receivership or they have incomplete data for the period covered. To achieve a consistent prediction, we ensured that the 48 companies that made the final sample fulfilled the following criteria; the company must have been listed on the floor of the London Stock Exchange before 2008, the Companies should have all the variables of interest considered in this study, the company must not be in receivership or liquidation, the variables of interest must be available for at least 6 out of 12 Calendar months, and the companies should have complete fiscal years for each of 2008 to 2018 studied.

The FTSE 350 index was selected because they represent the top 350 in the UK and have the potentials of providing more credible results for the variables of interest. Corporate Governance monitoring mechanisms, both internal and external are more applied among the FSE 350 companies. FTSE 350 companies' shares are widely subscribed by the Public, Institutions, Families as well as individuals. Regulations from the Financial Conduct Authority, Financial Reporting Council, the Stock Exchange, and Companies House which represent external Governance mechanisms are widely applied by the FTSE 350 companies. Being that the ownership structures of companies in the UK and US are believed to be dispersed which is one of the motivations for an investigation into the Agency theory issue, FTSE 350 companies offer the best representative of the study sample to investigate such phenomenon.

\subsection{Variables Description}

As earlier examined, this study investigates the impact of ownership structure on firms performance of the United Kingdom's FTSE 350 companies for the period 2008-2018. The variables of ownership structure and firm performance have been described in much detail below.

\section{Ownership structure (independent variable)}

While there are several measures of ownership structure studied by different researchers, the variables of managerial ownership and institutional ownership are considered in this study. As noted by Berle and Means (1932) and corroborated by Jensen \& Meckling (1976), the separation of ownership and control, as well as dispersed ownership, creates room for agency costs to rise in firms. As a means of minimizing agency costs, shares should be offered to managers to induce them into treating the company as theirs (managerial ownership). Managerial ownership is a potent incentive to managers where there is dispersed ownership structure because shareholders who have sufficiently spread their risks through diversification and hold little stakes in companies normally lack the drive to force managers to act responsibly and minimize agency costs (Jen- 
sen, 1986; Jensen \& Meckling, 1976).

Another way of influencing the behavior of managers and making them act in the best interest of the shareholders is through the influence of block shareholders (ownership concentration). Harryono (2020) believes that large shareholders have more reason to follow up the actions of management as it is evident that the fall of the company from the self-interest action of managers would be felt more by larger shareholders than small shareholders. Also, institutional investors (institutional ownership) are believed to monitor the actions of managers because they invest on behalf of other investors. Fung and Tsai (2012) argue that institutional investors are large shareholders and have more interest in tracking the activities of managers. The explanations given above justify why these variables have been selected as study variables influencing a firm's performance.

For this study, the variables mentioned above have been defined as follows:

- managerial_own = percent managerial ownership. This represents the sum of shares owned by the management, that is the executive director, board chairman and board members outstanding at the end of each fiscal year.

- inst_own = institutional ownership. This represents the number of shares owned by institutional investors. These investors have not been classified by whether they are "pressure-sensitive" or "pressure-insensitive".

- ownership concentration (dummy variable for managerial ownership above 5\%). Several studies like those of Shleifer and Vishny (1986), and Jensen and Meckling (1976) reported that managerial holding above certain thresholds erodes the benefit of managerial ownership by making the managers becoming powerful and insulated against monitoring processes by bloc shareholders or institutional holders. Balatbat et al. (2004) reported that managerial shareholding of between $25 \%$ - 50\% decreases firms' performance among Australian firms. However, among UK large listed companies, managerial ownership is below $5 \%$ and every ownership of $5 \%$ and above is considered to be ownership concentration. In this study, this entrenchment hypothesis is tested by making ownership concentration a dummy variable for shareholding above $5 \%$.

\section{Firms performance (dependent variable)}

In the study of the relationship between ownership structure and corporate performance, several measures of performance have been employed by researchers. While Demsetz and Lehn (1985) for instance used accounting profit rate of return as a measure of performance, subsequent studies have used Tobin's Q as a measure of performance (Demsetz \& Villalonga, 2001; Jeet et al., 2020). The use of either measure of performance has its benefits and limitations. The accounting profit rate of return is backward-looking, assessing what management has achieved in the past. Also, the accounting profit rate is heavily influenced by the Accountant's professional judgement and rules set by his/her professional bodies. Tobin's Q, on the other hand, is forward-looking, estimating what the future performance of a firm might be like. $Q$ is influenced by in- 
vestors' perception, reservations or positive belief about what the firm's performance might be in the future.

In light of this, the measures of performance used in this study are Tobin's $Q$ ratio (Predictive measure of performance), Return on Asset and Return on Capital Employed (accounting profit rate measures).

Therefore, these variables have been defined in the studies as follows:

- Return_On_Asset (ROA), is the ratio of Net profit as a percentage of net assets. Net Asset is either total assets minus total liabilities or shares capital plus reserves.

- Is_Roce_Company_Basis (Return on Capital Employed), defined as the measure of operating profit as a percentage of revenue.

- Tobin_Q_Ratio: this is the ratio of the market value of the firm divided by the replacement value of the tangible assets.

The above-mentioned variables have been constructed mathematically as follows:

FPERF $=\beta_{0}+\beta_{1}$ MGROWN $_{i, t}+\beta_{2}$ INSTOWN $_{i, t}+\beta_{3}$ OWNCON $_{i, t}+\mu_{i}$ where; FPERF = firm performance; MGROWN = Managerial ownership, INSTOWN = Institutional ownership and OWNCON = Ownership concentration (Dummy variable for managerial ownership higher than 5\%).

\subsection{Model and Analytical Approach}

\section{Panel data econometric model}

The panel data econometric model has been used in this research to investigate the impact of ownership structure on firm performance of UK's FTSE 350 companies for the period 2008-2018. Using panel data for investigation has key advantages over using a time series or cross-sectional data analysis models. Primarily, the panel data model allows for a greater level of accuracy in estimates because it has higher degrees of freedom (Barrow, 2017). Other advantages are, it is robust enough to enable it to capture the complexity of human behaviors with ease, it simplifies computation and predictive ability (Anderson, 2014). Since the longitudinal data model comprises time-series and cross-sectional data model approach, it combines the benefits of both models (Time series and Cross-section). Mathematically, the panel data model is constructed as follows;

$$
Y_{i t}=\alpha_{i}+\beta_{i t} \mu_{i t}+\mu_{i t}
$$

where; $\alpha_{i}$ represents an undefined intercept, $\beta_{i t}$ represents the vector of the parameter of interest and $\mu_{i t}$ represents the unobserved error term. That explains why the model for this study was constructed as follows FPERF $=\beta_{0}+\beta_{1}$ MGROWN $_{i, t}$ $+\beta_{2}$ INSTOWN $_{i, t}+\beta_{3} \mathrm{OWNCON}_{i, t}+\mu_{i}$.

Further, a quantitative data analysis method using the IBM SPSS 22 software was deployed in analyzing this data. The SPSS software makes data manipulation easy and possible and it is very suitable for data analysis in the social sciences. To fully answer the research questions and fulfill the research objectives, the following analysis was carried out. A descriptive statistical analysis covering the 
measures of central tendencies, dispersion and relationship; Ordinary Least Square (OLS) regression analysis of the independent and dependent variables; also Two-Stage Least Square (2SLS) regression analysis to test for endogeneity, and Post-regression diagnostic tests.

\section{Results and Discussion}

This section presents the results of the study. Advanced statistical analysis is conducted to help test the research hypothesis.

Description of variables.

1) $\mathrm{ROA}=$ Return on Assets

2) $\mathrm{ROE}=$ Return on Equity

3) $\mathrm{TOBINq}=$ market Value of firm

4) $\mathrm{PID}=$ Percent Independent Directors

5) $\mathrm{PWOB}=$ Percent Women on Firm Board

6) Inst_own = Institutional Ownership

7) Managerial_own = Percent Managerial ownership

8) Board_size $=$ Size of firm board

9) Own_cons = owner firm concentration (Dummy variable assuming 1 if managerial ownership is larger than or equal to $5 \%$ and zero otherwise)

Table 1 shows that both return on assets as well as returns on equity range from negative to positive percentages while the market value of the firm is a positive figure ranging from .79 to 12.3 . Between the two of them, however, the return on equity is the most unstable with a higher standard deviation of 27.49 compared to that return on assets which is 7.68. This might signify that measuring firms' performance using Return on Assets would provide a more consistent result. Q would be more appropriate where the performance of the firm has been consistently positive.

Table 1. Descriptive statistics.

\begin{tabular}{cccccc}
\hline & $\mathrm{N}$ & Minimum & Maximum & Mean & Std. Deviation \\
\hline ROA & 432 & -21.75 & 45.59 & 6.9366 & 7.68354 \\
ROE & 432 & -66.01 & 179.63 & 23.1596 & 27.49072 \\
TOBINQ & 432 & .79 & 12.30 & 1.9500 & 1.42123 \\
PID & 432 & 36.36 & 92.86 & 69.3300 & 11.35178 \\
PWOB & 432 & .00 & 50.00 & 21.4271 & 10.24651 \\
inst_own & 432 & .01 & 158.93 & 86.0529 & 22.89697 \\
managerial_own & 432 & .00 & 109.96 & 1.6600 & 10.01564 \\
board_size & 432 & 6.00 & 21.00 & 11.2106 & 2.40255 \\
Ownconc & 432 & .00 & 1.00 & .0440 & .20529 \\
Valid N (listwise) & 432 & & & & \\
\hline
\end{tabular}


Correlation coefficients provide useful insights into the relationship that exists among variables. The null hypothesis used in correlation analysis is that there is no significant pairwise association between pairs of variables. We reject the null hypothesis if the probability value of a test statistic is less than $5 \%$ and so we accept the alternative hypothesis.

The bivariate correlations in Table 2 indicate that return on assets is significantly correlated with return on equity, the value of the firm (Tobin's q) but not institutional ownership. The return on equity is significantly associated with Tobin's q but not institutional ownership structure.

Table 2. Correlations.

\begin{tabular}{|c|c|c|c|c|c|c|c|c|c|c|}
\hline & & ROA & ROE & TOBINQ & PID & PWOB & inst_own & managerial_own & board_size & ownconc \\
\hline & Pearson Correlation & 1 & $.683^{\star *}$ & $.645^{\star *}$ & -.023 & $.102^{*}$ & -.054 & $.426^{* *}$ & $-.325^{* *}$ & $.265^{\star *}$ \\
\hline \multirow[t]{3}{*}{ ROA } & Sig. (2-tailed) & & .000 & .000 & .630 & .034 & .267 & .000 & .000 & .000 \\
\hline & $\mathrm{N}$ & 432 & 432 & 432 & 432 & 432 & 432 & 432 & 432 & 432 \\
\hline & Pearson Correlation & $.683^{\star *}$ & 1 & $.539^{* *}$ & .051 & $.222^{\star *}$ & -.063 & $.250^{\star \star}$ & $-.129^{* *}$ & $.152^{* *}$ \\
\hline \multirow[t]{3}{*}{ ROE } & Sig. (2-tailed) & .000 & & .000 & .287 & .000 & .193 & .000 & .007 & .002 \\
\hline & $\mathrm{N}$ & 432 & 432 & 432 & 432 & 432 & 432 & 432 & 432 & 432 \\
\hline & Pearson Correlation & $.645^{\star *}$ & $.539^{* *}$ & 1 & .002 & $.162^{* *}$ & $-.128^{\star \star}$ & $.616^{* *}$ & $-.351^{\star \star}$ & $.433^{\star *}$ \\
\hline \multirow[t]{3}{*}{ TOBINQ } & Sig. (2-tailed) & .000 & .000 & & .966 & .001 & .008 & .000 & .000 & .000 \\
\hline & $\mathrm{N}$ & 432 & 432 & 432 & 432 & 432 & 432 & 432 & 432 & 432 \\
\hline & Pearson Correlation & -.023 & .051 & .002 & 1 & $.410^{\star *}$ & $-.280^{\star *}$ & $-.128^{\star *}$ & $.301^{\star *}$ & $-.252^{\star *}$ \\
\hline \multirow[t]{3}{*}{ PID } & Sig. (2-tailed) & .630 & .287 & .966 & & .000 & .000 & .008 & .000 & .000 \\
\hline & $\mathrm{N}$ & 432 & 432 & 432 & 432 & 432 & 432 & 432 & 432 & 432 \\
\hline & Pearson Correlation & $.102^{*}$ & $.222^{* *}$ & $.162^{\star *}$ & $.410^{* *}$ & 1 & $-.226^{* *}$ & $-.113^{*}$ & $.144^{* *}$ & $-.183^{* *}$ \\
\hline \multirow[t]{3}{*}{ PWOB } & Sig. (2-tailed) & .034 & .000 & .001 & .000 & & .000 & .019 & .003 & .000 \\
\hline & $\mathrm{N}$ & 432 & 432 & 432 & 432 & 432 & 432 & 432 & 432 & 432 \\
\hline & Pearson Correlation & -.054 & -.063 & $-.128^{\star *}$ & $-.280^{\star *}$ & $-.226^{\star *}$ & 1 & $-.167^{\star *}$ & $-.270^{\star *}$ & -.080 \\
\hline \multirow[t]{3}{*}{ inst_own } & Sig. (2-tailed) & .267 & .193 & .008 & .000 & .000 & & .000 & .000 & .098 \\
\hline & $\mathrm{N}$ & 432 & 432 & 432 & 432 & 432 & 432 & 432 & 432 & 432 \\
\hline & Pearson Correlation & $.426^{* *}$ & $.250^{* *}$ & $.616^{* *}$ & $-.128^{* *}$ & $-.113^{*}$ & $-.167^{\star *}$ & 1 & $-.200^{* *}$ & $.628^{\star *}$ \\
\hline \multirow[t]{3}{*}{ managerial_own } & Sig. (2-tailed) & .000 & .000 & .000 & .008 & .019 & .000 & & .000 & .000 \\
\hline & $\mathrm{N}$ & 432 & 432 & 432 & 432 & 432 & 432 & 432 & 432 & 432 \\
\hline & Pearson Correlation & $-.325^{\star *}$ & $-.129^{* *}$ & $-.351^{* *}$ & $.301^{* *}$ & $.144^{* *}$ & $-.270^{\star *}$ & $-.200^{* *}$ & 1 & $-.193^{\star *}$ \\
\hline \multirow[t]{3}{*}{ board_size } & Sig. (2-tailed) & .000 & .007 & .000 & .000 & .003 & .000 & .000 & & .000 \\
\hline & $\mathrm{N}$ & 432 & 432 & 432 & 432 & 432 & 432 & 432 & 432 & 432 \\
\hline & Pearson Correlation & $.265^{\star *}$ & $.152^{\star *}$ & $.433^{* *}$ & $-.252^{* *}$ & $-.183^{* *}$ & -.080 & $.628^{* *}$ & $-.193^{* *}$ & 1 \\
\hline \multirow[t]{2}{*}{ Ownconc } & Sig. (2-tailed) & .000 & .002 & .000 & .000 & .000 & .098 & .000 & .000 & \\
\hline & $\mathrm{N}$ & 432 & 432 & 432 & 432 & 432 & 432 & 432 & 432 & 432 \\
\hline
\end{tabular}

**. Correlation is significant at the .01 level (2-tailed). *. Correlation is significant at the .05 level (2-tailed). 
From the pooled regression in Table 3, we see that a large percentage of independent directors on the board significantly influence firms 'performance. Institutional ownership structure decreases firm performance but not in a significant way according to the OLS results. It appears only managerial ownership structure does affect firm performance (i.e. increase return on assets) positively and significantly. The surprising result is that of board size which has the effect of decreasing firm performance. The $\mathrm{F}$ statistical probability is below $5 \%$ and implies that a pooled regression is a valid analysis and the results can be trusted.

\section{Endogeneity test}

Independent variables in a regression must be exogenous otherwise, if not, the results may be spurious. We need to test the exogeneity/endogeneity of the variables so that if some of them are endogenous then we can make use of instruments to proxy them. The test of endogeneity is done through the 2SLS estimation as shown below.

The 2SLS is an instrumental variable estimation. The results in Table 4 look like those obtained through OLS in Table 3 and so this means that we do not have endogenous predictors. We can therefore trust that the regressors are truly independent.

\section{Hausman Specification test}

Before deciding on which would be the best regression approach between the Fixed Effects and the Random Effects model, we had to perform the Hausman Specification test and the result was to reject the null hypothesis of coefficients being unsystematic. The Fixed Effects model fitted the data better (see the test results below).

The null hypothesis tested in Table 5 shows that the better model to use is the Random Effects model. The probability of the Chi-Square statistic, however, is far less than the 5 percent level of significance meaning that we reject the Ho in favour of estimation of the Fixed Effects model.

Table 3. Pooled (OLS) regression.

\begin{tabular}{ccccccc}
\hline Source & ss & df & MS & Number of obs & 432 \\
\hline Model & 6456.80463 & 5 & 1291.36093 & $\mathrm{~F}(5,426)$ & 28.97 \\
Residual & $18,988.0474$ & 426 & 44.5728813 & Prob $>$ F & .0000 \\
Total & $25,444.8521$ & 431 & 59.0367797 & R-squared & .2538 \\
& & & & & Adj R-squared & .2450 \\
& & & & & Root MSE & .6763 \\
\hline Roa & Coef. & Std. Err. & $\mathrm{t}$ & $p>|\mathrm{t}|$ & {$[95 \%$ Conf. Interval] } \\
\hline Inst_own & -.0141422 & .0154745 & -.91 & .361 & -.0445581 & .0162737 \\
Managerial_own & .2891752 & .0422472 & 6.84 & .000 & .2061364 & .3722141 \\
Board_size & -.9334868 & .1471827 & -6.34 & .000 & -1.222781 & -.644192 \\
ownconc & -.225583 & 2.06647 & -.11 & .913 & -4.28733 & 3.836164 \\
pid & .0673882 & .0313898 & 2.15 & .032 & .00569 & .1290864 \\
_cons & 13.47644 & 3.26133 & 4.13 & .000 & 7.06614 & 19.88674 \\
\hline
\end{tabular}


Table 4. Endogeneity test Instrumental variables (2SLS) regression.

\begin{tabular}{ccccccc}
\hline Source & SS & df & \multicolumn{2}{c}{ MS } & Number of obs & 432 \\
\hline Model & 6456.80463 & 5 & 1291.36093 & F $(5,426)$ & 28.97 \\
Residual & $18,988.0474$ & 426 & 44.5728813 & Prob $>$ F & .0000 \\
Total & $25,444.8521$ & 431 & 59.0367797 & R-squared & .2538 \\
& & & & & Adj R-squared & .2450 \\
& & & & & Root MSE & 6.6763 \\
\hline roa & Coef. & Std.Err. & $\mathrm{t}$ & \multicolumn{2}{c}{$p>|\mathrm{t}|$} & {$[95 \%$ Conf. Interval] } \\
\hline inst_own & -.0141422 & .0154745 & -.91 & .361 & -.0445581 & .0162737 \\
managerial_own & .2891752 & .0422472 & 6.84 & .000 & .2061364 & .3722141 \\
board_size & -.9334868 & .1471827 & -6.34 & .000 & -1.222781 & -.644192 \\
ownconc & -.225583 & 2.06647 & -.11 & .913 & -4.28733 & 3.836164 \\
pid & .0673882 & .0313898 & 2.15 & .032 & .00569 & .1290864 \\
_cons & 13.47644 & 3.26133 & 4.13 & .000 & 7.06614 & 19.88674 \\
\hline
\end{tabular}

(No endogenous regressors).

Table 5. Hausman Specification test.

Test: Ho: difference in coefficients not systematic

$\operatorname{chi} 2(6)=(b-B)^{\prime}\left[\left(V \_b-V \_B\right)^{(-1)}\right](b-B)=125.39$

Prob $>$ chi $2=.0000$

As seen in Table 6, Institutional ownership has a negative impact on returns on assets. However, higher percentages of managerial ownership have a positive and highly significant impact on returns on assets. This might imply that allotting shares to managers makes them see the business as theirs, therefore, enhancing firms' performance. Ownership concentration (Dummy variable for managerial ownership above 5\%) has a negative relationship with returns on assets. This may mean that if management ownership of shares goes above $5 \%$ or more, firms' performance would be on the decline.

The appearance of control variables in Table 7 has changed the dynamics to some extent. Having independent directors increases returns on assets. Having more women on board increases returns on assets but not so significantly. Management ownership of shares above 5\% does increase return on assets but, again, not in a significant way. The only variable that is significant with or without control variables is the managerial ownership variable.

\section{Testing Null Hypotheses}

\section{Hypothesis 1.}

Ho: Institutional ownership has no significant impact on firms' performance

At 5\% significance level and a $P$-value of .665, we see that the $P$-value is $.665>.05$ 
Table 6. Fixed effects regression of returnon assets onpredictors.

\begin{tabular}{|c|c|c|c|c|c|}
\hline \multicolumn{3}{|c|}{ Fixed-effects (within) regression } & Number of obs & $=$ & 432 \\
\hline \multicolumn{3}{|l|}{ Groupvariable: id } & Number of groups & $=$ & 48 \\
\hline R-sq: within & .0156 & & Obs per group: $\min$ & $=$ & 9 \\
\hline between & .3607 & & avg & $=$ & 9.0 \\
\hline overall & .1658 & & $\max$ & $=$ & 9 \\
\hline & & & $F(3,381)$ & $=$ & 2.01 \\
\hline $\operatorname{corr}\left(\mathrm{u} \_\mathrm{i}, \mathrm{Xb}\right)$ & .3895 & & Prob $>F$ & $=$ & .1118 \\
\hline roa & Coef. & Std. Err. & $P>|\mathrm{t}|$ & \multicolumn{2}{|c|}{ [95\% Conf. Interval] } \\
\hline inst_own & -.0130599 & .0192292 & -.68 & -.0508685 & .0247487 \\
\hline managerial_own & .1076007 & .047947 & 2.24 & .0133268 & .2018746 \\
\hline ownconc & -.1000626 & 2.211492 & -.05 & -4.448319 & 4.248194 \\
\hline _cons & 7.886233 & 1.687681 & 4.67 & 4.567899 & 11.20457 \\
\hline sigma_u & 5.1199723 & & & & \\
\hline sigma_e & 5.5697053 & & & & \\
\hline rho & .45800262 & & tion of variance due to & & \\
\hline
\end{tabular}

F test that all $u_{-} i=0: F(47,381)=6.17$ Prob $>F=.0000$.

Table 7. Fixed effects regression of returnon assets with control variables.

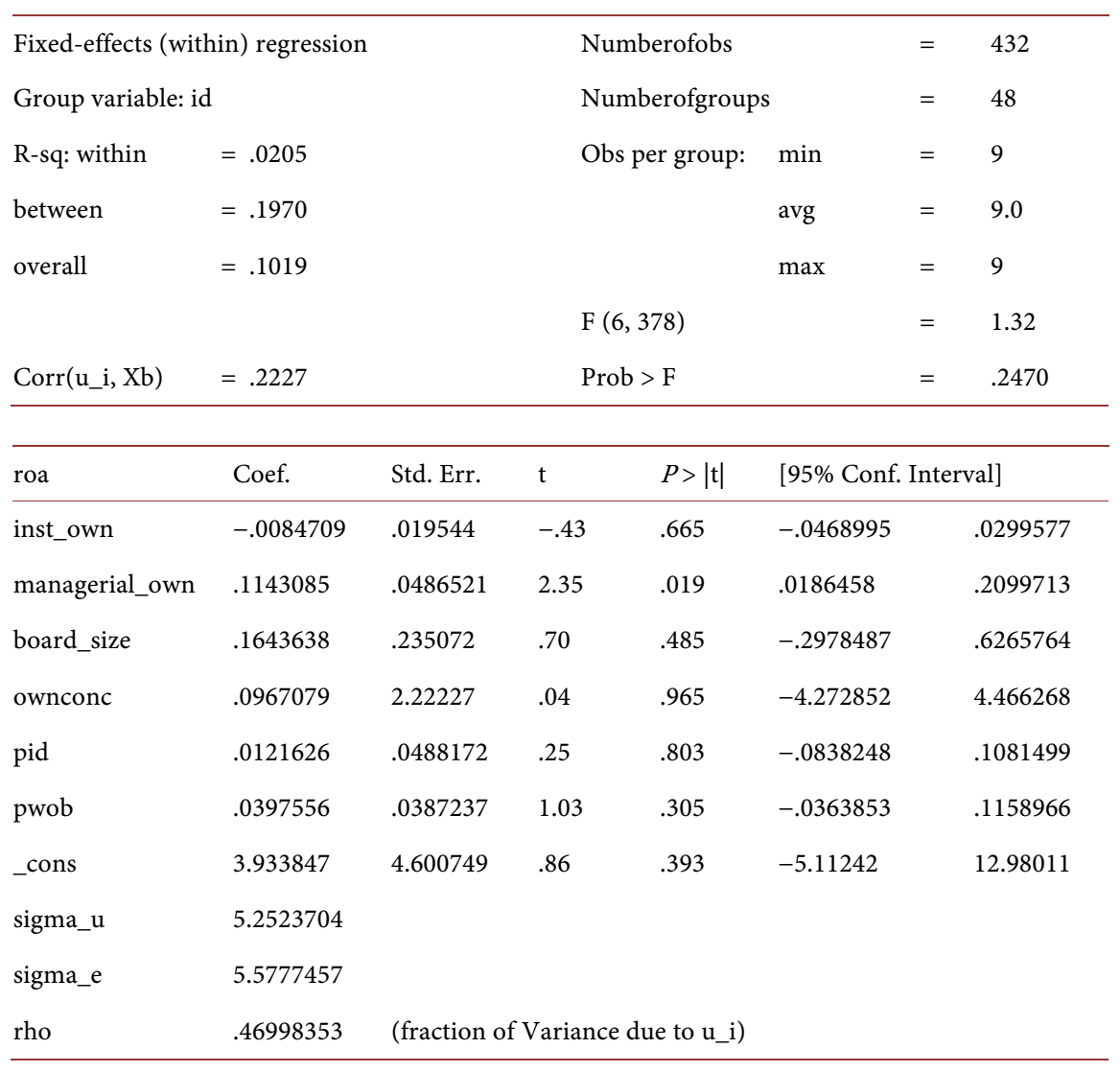

F test that all $\mathrm{u}_{-} \mathrm{i}=0: \mathrm{F}(47,378)=4.55$ Prob $>\mathrm{F}=.0000$. 
Decision: we do not reject the null hypothesis and conclude that institutional ownership does not significantly impact firms' performance.

\section{Hypothesis 2.}

1) Ho: Managerial ownership has no significant impact on firms' performance

At $5 \%$ significance level and a $P$-value of .019, we see that the $P$-value is less than the significance level $(.019<.05)$.

Decision: we reject the null hypothesis at the $5 \%$ level of significance. We, therefore, conclude that the Managerial Ownership structure is significant in explaining return on assets. This means that an ownership structure where managers are allotted some measure of ownership influences firms' performance positively.

2) Ho: There is no managerial entrenchment at managerial ownership above $5 \%$

At $5 \%$ significance level and a $P$-value of .965 , we see that the $P$-value is $.965>.05$

Decision: we do not reject the null hypothesis and conclude that managerial entrenchment there is no managerial entrenchment among the FTSE 350.

\section{Hypothesis 3}

Ho: There is no bi-directional impact between ownership structure and firm performance

The 2SLS regression produced the same result as the OLS regression. This indicates that ownership structure is not endogenous to firms' performance.

The results in Table 8 show that both higher percentages of institutional ownership reduce the return on equity. Managerial ownership helps to increase returns on equity but not significantly. Ownership concentration improves firm performance.

Table 8. Fixed effects regression of return on equity (without control variables).

\begin{tabular}{|c|c|c|c|c|c|c|}
\hline \multicolumn{3}{|c|}{ Fixed-effects (within) regression } & \multicolumn{3}{|c|}{ Number of obs } & 432 \\
\hline \multicolumn{3}{|l|}{ Group variable: id } & \multicolumn{3}{|c|}{ Number of groups } & 48 \\
\hline R-sq: within & $=.0049$ & & \multicolumn{2}{|c|}{ Obs per group: } & $\min$ & $=$ \\
\hline between & $=.1026$ & & & & avg & 9.0 \\
\hline \multirow[t]{2}{*}{ overall } & $=.0584$ & & & & $\max$ & $=$ \\
\hline & & & \multicolumn{3}{|c|}{$\mathrm{F}(3,381)$} & $=.62$ \\
\hline $\operatorname{corr}\left(\mathrm{u} \_\mathrm{i}, \mathrm{Xb}\right)$ & $=.2084$ & & \multicolumn{3}{|c|}{ Prob $>$ F } & .6012 \\
\hline roe & Coef. & Std. Err. & $\mathrm{t}$ & $P>|\mathrm{t}|$ & \multicolumn{2}{|c|}{ [95\% Conf. Interval] } \\
\hline inst_own & -.0035857 & .0587106 & -.06 & .951 & -.1190231 & .1118516 \\
\hline managerial_own & .1597795 & .1463918 & 1.09 & .276 & -.1280576 & .4476165 \\
\hline ownconc & 3.214506 & 6.752128 & .48 & .634 & -10.06159 & 16.49061 \\
\hline _cons & 23.06156 & 5.152828 & 4.48 & .000 & 12.93002 & 33.1931 \\
\hline sigma_u & 22.038319 & & & & & \\
\hline sigma_e & 17.00543 & & & & & \\
\hline rho & .62679696 & (fraction & ariance du & to $\mathrm{u} \_\mathrm{i}$ ) & & \\
\hline
\end{tabular}

F test that all u_i $=0: \mathrm{F}(47,381)=14.34$ Prob $>\mathrm{F}=.0000$. 
The inclusion of control variables in Table 9 had a positive effect on independent variables on return on equity. All independent variables have a positive effect on return on equity. This means having women on board is important for firm performance just as independent directors have on the firm.

At this stage, Table 10 indicates that all independent variables have no significant impact on the value of a firm. It would be interesting to see how the introduction of control variables would mean for econometric results.

Introducing control variables in Table 11 in the regression has not changed the dynamics that much. The relationship between the firm' value (Tobin's q) and ownership structure stays the same but what can be seen is that having a higher percentage of independent directors does increase the value of the firm while increasing the percentage of women on board also does increase the value of the firm significantly.

\section{Discussion of Findings}

\section{Managerial ownership and firms' performance}

HO: Managerial ownership has no significant impact on firms' performance

Findings: we reject the null hypothesis at $5 \%$ level significance level and conclude that managerial ownership has a significant negative impact on firms' performance.

Table 9. Fixed effects regression of return on equity with control variables.

\begin{tabular}{|c|c|c|c|c|c|c|}
\hline \multicolumn{3}{|c|}{ Fixed-effects (within) regression } & \multicolumn{3}{|c|}{ Number of obs } & 432 \\
\hline \multicolumn{3}{|l|}{ Group variable: id } & \multicolumn{3}{|c|}{ Number of groups } & 48 \\
\hline R-sq: within & $=.0225$ & & \multicolumn{2}{|c|}{ Obs per group: } & $\min$ & $=$ \\
\hline between & $=.1040$ & & & & avg & 9.0 \\
\hline \multirow[t]{2}{*}{ overall } & $=.0697$ & & & & $\max$ & $=$ \\
\hline & & & \multicolumn{3}{|c|}{$\mathrm{F}(6,378)$} & 1.45 \\
\hline $\operatorname{corr}\left(\mathrm{u} \_\mathrm{i}, \mathrm{Xb}\right)$ & $=.1455$ & & \multicolumn{3}{|c|}{ Prob $>$ F } & .1943 \\
\hline roe & Coef. & Std. Err. & $\mathrm{t}$ & $P>|\mathrm{t}|$ & \multicolumn{2}{|c|}{ [95\% Conf. Interval] } \\
\hline inst_own & .0203023 & .0592895 & .34 & .732 & -.0962762 & .1368808 \\
\hline managerial_own & .217275 & .1475929 & 1.47 & .142 & -.072931 & .5074811 \\
\hline board_size & .3027486 & .7131231 & .42 & .671 & -1.099437 & 1.704934 \\
\hline ownconc & 4.400791 & 6.741562 & .65 & .514 & -8.85487 & 17.65645 \\
\hline pid & .2220652 & .1480938 & 1.50 & .135 & -.0691256 & .513256 \\
\hline pwob & .1762324 & .1174738 & 1.50 & .134 & -.0547517 & .4072164 \\
\hline _cons & -1.707631 & 13.957 & -.12 & .903 & -29.15072 & 25.73546 \\
\hline sigma_u & 21.690988 & & & & & \\
\hline sigma_e & 16.920858 & & & & & \\
\hline rho & .62168341 & (fraction & ariance & e to $u_{-} i$ ) & & \\
\hline
\end{tabular}

F test that all $\mathrm{u} \_\mathrm{i}=0: \mathrm{F}(47,378)=12.77$ Prob $>\mathrm{F}=.0000$. 
Table 10. Fixed Effects Regression of Tobin's q on predictors (without control variables).

\begin{tabular}{|c|c|c|c|c|c|c|}
\hline \multicolumn{3}{|c|}{ Fixed-effects (within) regression } & \multicolumn{3}{|c|}{ Number of obs } & $=432$ \\
\hline \multicolumn{3}{|c|}{ Group variable: id } & \multicolumn{3}{|c|}{ Number of groups } & 48 \\
\hline R-sq: within & $=.0292$ & & \multicolumn{3}{|c|}{ Obs per group: } & $=$ \\
\hline between & $=.4414$ & & & & avg & 9.0 \\
\hline \multirow[t]{2}{*}{ overall } & $=.2504$ & & & & $\max$ & $=$ \\
\hline & & & \multicolumn{3}{|c|}{$\mathrm{F}(3,381)$} & $=3.81$ \\
\hline $\operatorname{corr}\left(\mathrm{u} \_\mathrm{i}, \mathrm{Xb}\right)$ & $=-.5854$ & & \multicolumn{3}{|c|}{ Prob $>$ F } & .0103 \\
\hline tobinq & Coef. & Std. Err. & $\mathrm{t}$ & $P>|\mathrm{t}|$ & \multicolumn{2}{|c|}{ [95\% Conf. Interval] } \\
\hline inst_own & -.0022419 & .0014986 & -1.50 & .135 & -.0051884 & .0007047 \\
\hline managerial_own & -.0060818 & .0037367 & -1.63 & .104 & -.0134289 & .0012653 \\
\hline ownconc & -.3677325 & .1723496 & -2.13 & .034 & -.7066081 & -.028857 \\
\hline _cons & 2.169189 & .1315271 & 16.49 & .000 & 1.910579 & 2.427799 \\
\hline sigma_u & 1.4453515 & & & & & \\
\hline sigma_e & .4340675 & & & & & \\
\hline rho & .91726969 & (fraction $\mathrm{c}$ & f varian & e due to & & \\
\hline
\end{tabular}

F test that all $\mathrm{u}_{-} \mathrm{i}=0: \mathrm{F}(47,381)=52.53$ Prob $>\mathrm{F}=.0000$.

Table 11. Fixed effects regression of tobin's q on predictors \& control variables.

\begin{tabular}{|c|c|c|c|c|c|c|c|}
\hline \multicolumn{3}{|c|}{ Fixed effects (within) regression } & \multicolumn{3}{|c|}{ Number of obs } & $=$ & 432 \\
\hline \multicolumn{3}{|l|}{ Group variable: id } & \multicolumn{3}{|c|}{ Number of groups } & $=$ & 48 \\
\hline R-sq: within & $=.0784$ & & \multirow{2}{*}{\multicolumn{2}{|c|}{ Obs per group: }} & $\min$ & $=$ & 9 \\
\hline between & $=.0955$ & & & & avg & $=$ & 9.0 \\
\hline \multirow[t]{2}{*}{ overall } & $=.0455$ & & & & $\max$ & $=$ & 9 \\
\hline & & & \multicolumn{3}{|c|}{$\mathrm{F}(6,378)$} & $=$ & 5.36 \\
\hline $\operatorname{corr}\left(\mathrm{u} \_\mathrm{i}, \mathrm{Xb}\right)$ & $=-.3710$ & & \multicolumn{3}{|c|}{ Prob $>$ F } & $=$ & .0000 \\
\hline tobinq & Coef. & Std. Err. & $\mathrm{t}$ & $P>|\mathrm{t}|$ & \multicolumn{3}{|c|}{ [95\% Conf. Interval] } \\
\hline inst_own & -.001256 & .0014877 & -.84 & .399 & -.0041812 & & .0016692 \\
\hline managerial_own & -.0035724 & .0037034 & -.96 & .335 & -.0108543 & & .0037096 \\
\hline board_size & .0145389 & .0178939 & .81 & .417 & -.0206451 & & .0497229 \\
\hline ownconc & -.3214451 & .1691611 & -1.90 & .058 & -.6540596 & & .0111695 \\
\hline pid & .011221 & .003716 & 3.02 & .003 & .0039144 & & .0185277 \\
\hline pwob & .0061214 & .0029477 & 2.08 & .039 & .0003255 & & .0119173 \\
\hline _cons & 1.006041 & .3502128 & 2.87 & .004 & .3174313 & & 1.69465 \\
\hline sigma_u & 1.4461505 & & & & & & \\
\hline sigma_e & .42458264 & & & & & & \\
\hline rho & .92064241 & (fraction & variance & ue to $u \_i$ ) & & & \\
\hline
\end{tabular}

F test that all $\mathrm{u}_{-} \mathrm{i}=0$ : $\mathrm{F}(47,378)=41.89$ Prob $>\mathrm{F}=.0000$. 
The OLS regression analysis in Table 3 showed that Managerial ownership has a positive impact on the performance measures of Return of Asset and return on Equity but a negative relationship with Q. The hypothesis testing at 5\% level of significance confirms that managers owning shares in the company that they run positively and significantly improves firms' performance. This finding is in line with the findings of Jensen and Meckling (1976); Morck et al. (1988); McConnell and Servaes (1995); Balatbat et al. (2004); Bolton (2012); Agrawal and knoeber (1996); Chang (2003); Morck et al. (1988); and Mehran (1995). Specifically, this study confirms the "interest alignment hypothesis" where Jensen and Meckling (1976) first stated that allotting shares to managers helps to dissuade them from engaging in self-interest activities that erodes the value of the firm. As discussed in the literature review, dispersed ownership structure arrangement should cause a decrease in performance because effective monitoring is absent by shareholders (Berle \& Means, 1932). However, the shareholders can mitigate this by making arrangements for managerial share ownership which will ensure that they "bond" with the organisation, therefore, increasing the firm's performance. This finding did not show the case of the entrenchment hypothesis. The dummy variable of the managerial ownership of shares above $5 \%$ also showed a positive impact on firms' performance. The entrenchment hypothesis may not be an issue among the FTSE 350 firms as there is no managerial ownership exceeding $5 \%$ in all the companies studied. This finding is contrary to those of Jensen and Murphy (1990), Slovin and Sushka (1993), Boyle et al. (1998), and Agrawal and Mandelker (1990) who reported a negative relationship between shares owned by management and corporate performance. The findings also contradict the findings of Demsetz and Villalonga (2001) and Loderer and Martin (1997) who found no relationship between managerial ownership and firms' performance.

\section{Institutional ownership and firms' performance}

HO: Institutional ownership has no significant impact on firms' performance.

Findings: We do not reject the null hypothesis at 5\% level of significance and conclude that institutional ownership has no significant impact on firms' performance.

The pooled regression result in Table 3 showed that if Institutional shareholding increases by 1 percentage point, then on an average, firms' performance measured by return on asset decreases by .014 percentage point. Institutional ownership had negative effects on $\mathrm{Q}$ and a marginally positive impact on Return on Equity when measured on a fixed effect regression on control variables.

However, testing the impact of institutional ownership on performance at a $5 \%$ level of significance showed that there is no significant impact of Institutional ownership on firms' performance. This finding is in line with similar findings on the previous study of how Institutional ownership impacts firms' performance by Faccio and Lasfer (2000), Duggal and Miller (1999), Karpoff et al. (1996) and Agrawal and Knoeber (1996). This finding may be this way because when shares owned by Institutional shareholders are not bulky, they can easily 
liquidate their ownership and move on, therefore, making their impact not to be felt (Shleifer \& Vishny, 1986). Also, institutional investors may choose to rather diversify their portfolios by holding small units of shares in many firms across different industrial sectors than hold large portions in a single company or industry The finding is contrary to the findings of McConnell and Servaes (1995), Nesbitt (1994), Smith (1776) and Del Guercio and Hawkins (1999), and Cornett et al. (2007) who all found a significant positive relationship between institutional ownership and firms' performance. In their studies, they believe that large institutional investors pressure managers into taking firms' enhancing decisions. The result is also contrary to the studies of Brickley et al. (1988); Almazan et al. (2005); Chen et al. (2011) who found a significant negative relationship between institutional shareholding and firms' performance. They believe that such negative impacts are attributed to the fact that pressure-sensitive institutional investors rather depreciate the value of firms by acting in their self-interests.

\section{Endogeneity of firms' performance and ownership structure}

HO: There is no bi-directional impact between ownership structure and firm performance.

Finding: The 2SLS regression produced the same result as the OLS regression therefore the hypothesis was not tested.

The 2 Level Least Squared regression analysis output in Table 4 is the same as that of the Ordinary Least squared regression analysis in Table 3. This result gave no initial indication of the two-way direction of impact between performance and ownership structure as inferred by Demsetz (1983). This finding is contrary to that of Kole (1996), who found that managerial ownership is endogenous to compensation but in line with those of Foroughi and Fooladi (2011); who found no significant influence of firms' performance on ownership structure. This study did not consider a simultaneous equation or any other approach in trying to determine if firms' performance influences ownership structure. This rather leaves room for further studies in this area.

\section{Conclusion}

Based on the fixed-effects model regression analysis, we find that: all ownership structures have a positive effect on return on equity though not significantly. "Ownership concentration" (managerial ownership dummy variable for a shareholding over 5\%) had a positive impact on the return on equity. Again, all independent variables except the institutional ownership variable had a positive effect on return on assets. The managerial ownership variable was the only one with a significant impact on assets. Regarding the value of the firm (Tobin's $Q$ ), none of the ownership structures had a significant effect on it. Only control variables such as percentage of independent directors as well as the percentage of women on the board and the firm size were positively related to the Tobin q variable. Ownership structure does positively affect firm performance.

From the angle of hypothesis testing, we find that Managerial ownership has a 
significant positive impact on firms' performance at a 5\% level of significance. This finding is corroborated with the studies of Jensen and Meckling (1976); Morck et al. (1988); McConnell and Servaes (1995); Balatbat et al. (2004); Bolton (2012); Agrawal and Knoeber (1996); Chang (2003); Morck et al. (1988); and Mehran (1995). These findings sustain the initial interest alignment hypothesis of Jensen and Meckling (1976) which states that the most potent way of getting managers to act in utmost good of the firm is by managerial share ownership. Making ownership concentration a dummy variable for managers' shares held over 5\% did not reveal any managerial entrenchment effect. Share ownership exceeding $5 \%$ for managerial ownership was tested for entrenchment, because share ownership in the UK is diffused and managerial shares ownership for almost all firms studied was grossly below $5 \%$.

Also, at a 5\% level of significance, we find that institutional ownership does not have a significant impact on firms' performance. This finding also aligns with the findings of Faccio and Lasfer (2000), Duggal and Miller (1999), Karpoff et al. (1996) and Agrawal and Knoeber (1996). The only thing surprising about this finding is that average Institutional ownership for almost all FTSE 350 is above $50 \%$ which should have produced a definitive negative or positive impact.

The issue of endogeneity was first raised by Demsetz (1983) and several researchers have tried investigating the reverse impact of firms' performance on ownership structure. In this study, a 2SLS did not reveal any endogeneity. Kole (1996) for instance tried investigating the reverse impact of firms' performance on managerial ownership and found that managerial ownership was endogenous to compensation packages rather than firms' performance. We conclude in this study that firms' performance is neither endogenous to managerial or institutional ownership.

From the fixed effects regression model analysis, we find that a control variable like the percentage of Independent directors on the board positively impacts all measures of firms' performance (ROA, ROE and Q) but when tested at a 5\% significance level, this impact is found to be statistically insignificant. Also, the control variable of the percentage of women on the board is found to impact firms' performance negatively and yet this impact is statistically insignificant at a $5 \%$ level of significance hypothesis testing.

This research brings contributions in four distinct ways. Firstly, this research lends another credence to the findings on the impact of managerial ownership on corporate performance. The finding further confirms that managerial ownership improves a firm's performance and there is no indication of managerial entrenchment in UK public companies because of the diffuseness of ownership. Also, the findings on institutional ownership, percentage of independent directors on the board and women on the board add to the myriads of literature in this area. Secondly, the regulatory authorities may have a reason to identify which areas to concentrate on in writing governance codes for listed companies. For instance, the policy on making sure that companies increase the number of 
independent directors on the Board can better be enforced to ensure that firms' performance is increased. Thirdly, the findings offer academia the opportunity to investigate further the cause of variation in firms' performance, particularly the issue of the bi-directional impact of performance and ownership. Fourthly, the UK FTSE 350 index has the information at its purview to find avenues of increasing the percentage of women on the board as well as offering them the platform to work to their fullest potentials.

\subsection{Limitations of the Study}

The data for the variables of interest were derived from public companies. Private companies were not studied, although they appear to be strong drivers of the UK economy. Also, the methodology adopted for establishing endogeneity could have been done using the simultaneous equation approach rather than a 2LS.

\subsection{Recommendations}

Considering the results and the subsequent conclusions above, it is hereby recommended that:

1) There should be further studies in this area considering private companies as well as increasing the sample size because private companies constitute a significant portion of the UK's economy.

1) More corporate governance codes or outright regulations should be made increasing the ratio of independent directors on the board more than the current ratio. This will ensure that the impact of having independent directors on the board becomes statistically significant.

3) Further investigation into the findings on the percentage of women on the board to decipher if the statistical insignificance of having women on the board is due to less representation of women on the board or lack of the opportunity provided to them to make meaningful contributions.

4) More studies on the possibility of "managerial entrenchment" on ownership above $5 \%$ should be investigated with a larger sample size among listed companies in the UK.

5) A non-linear model should be used in estimating the influence of institutional ownership on firms' performance and in testing the possibility of firms' performance influencing ownership structure.

\section{Conflicts of Interest}

The authors declare no conflicts of interest regarding the publication of this paper.

\section{References}

Agrawal, A., \& Knoeber, C. (1996). Firm Performance and Mechanisms to Control Agency Problems between Managers and Shareholders. The Journal of Financial and Quantitative Analysis, 31, 377-397. https://doi.org/10.2307/2331397 
Agrawal, A., \& Mandelker, G. (1990). Large Shareholders and the Monitoring of Managers: The Case of Antitakeover Charter Amendments. The Journal of Financial and Quantitative Analysis, 25, 143-161. https://doi.org/10.2307/2330821

Almazan, A., Hartzell, J., \& Starks, L. (2005). Active Institutional Shareholders and Costs of Monitoring: Evidence from Executive Compensation. Financial Management, 34, 5-34.

Ameer, R., Ramli, F., \& Zakaria, H. (2010). A New Perspective on Board Composition and Firm Performance in an Emerging Market. Corporate Governance: The International Journal of Business in Society, 10, 647-661. https://doi.org/10.1108/14720701011085607

Anderson, D. (2014). Statistics for Business and Economics (12th ed.). Cengage Learning.

Babatunde, M., \& Olaniran, O. (2009). The Effects of Internal and External Mechanism on Governance and Performance of Corporate Firms in Nigeria. Corporate Ownership and Control, 7, 330-342. https://doi.org/10.22495/cocv7i2c3p1

Balatbat, M., Taylor, S., \& Walter, T. (2004). Corporate Governance, Insider Ownership and Operating Performance of Australian Initial Public Offerings. Accounting \& Finance, 44, 299-328. https://doi.org/10.1111/j.1467-629x.2004.00114.x

Barclay, M., Holderness, C., \& Sheehan, D. (2007). Private Placements and Managerial Entrenchment. Journal of Corporate Finance, 13, 461-484.

https://doi.org/10.1016/j.jcorpfin.2007.04.009

Barrow, M., (2017). Statistics for Economics, Accounting and Business Studies. Pearson Education Limited.

Berle, A., \& Means, G. (1932). The Modern Corporation and Private Property. Commerce Clearing House.

Bolton, B. (2012). Audit Committee Performance: Ownership vs. Independence-Did SOX Get It Wrong? Accounting \& Finance, 54, 83-112. https://doi.org/10.1111/j.1467-629X.2012.00504.x

Boyle, G., Carter, R., \& Stover, R. (1998). Extraordinary Antitakeover Provisions and Insider Ownership Structure: The Case of Converting Savings and Loans. The Journal of Financial and Quantitative Analysis, 33, 291-304. https://doi.org/10.2307/2331311

Brickley, J., Lease, R., \& Smith Jr., C. (1988). Ownership Structure and Voting on Antitakeover Amendments. Journal of Financial Economics, 20, 267-291. https://doi.org/10.1016/0304-405X(88)90047-5

Chang, S. (2003). Ownership Structure, Expropriation, and Performance of Group-Affiliated Companies in Korea. Academy of Management Journal, 46, 238-253.

Chen, D., Bin, F., \& Chen, C. (2011). The Impacts of Political Events on Foreign Institutional Investors and Stock Returns: Emerging Market Evidence from Taiwan. International Journal of Business, 10, 165-174.

Cornett, M., Marcus, A., Saunders, A., \& Tehranian, H. (2007). The Impact of Institutional Ownership on Corporate Operating Performance. Journal of Banking \& Finance, 31, 1771-1794. https://doi.org/10.1016/j.jbankfin.2006.08.006

Demsetz, H. (1983). The Structure of Ownership and the Theory of the Firm. The Journal of Law \& Economics, 26, 375-390. http://www.jstor.org/stable/725108 https://doi.org/10.1086/467041

Demsetz, H., \& Lehn, K. (1985). The Structure of Corporate Ownership: Causes and Consequences. Journal of Political Economy, 93, 1155-1177.

https://doi.org/10.1086/261354

Demsetz, H., \& Villalonga, B. (2001). Ownership Structure and Corporate Performance. 
Journal of Corporate Finance, 7, 209-233.

https://doi.org/10.1016/S0929-1199(01)00020-7

Denis, D., \& McConnell, J. (2003). International Corporate Governance. The Journal of Financial and Quantitative Analysis, 38, 1-36. https://doi.org/10.2307/4126762

Duggal, R., \& Millar, J. (1999). Institutional Ownership and Firm Performance: The Case of Bidder Returns. Journal of Corporate Finance, 5, 103-117. https://doi.org/10.1016/S0929-1199(98)00018-2

Elyasiani, E., \& Jia, J. (2010). Distribution of Institutional Ownership and Corporate firm Performance. Journal of Banking \& Finance, 34, 606-620.

https://doi.org/10.1016/j.jbankfin.2009.08.018

Faccio, M., \& Lasfer, M. (2000). Do Occupational Pension Funds Monitor Companies in Which They Hold Large Stakes? Journal of Corporate Finance, 6, 71-110. https://doi.org/10.1016/S0929-1199(99)00016-4

Fama, E., \& Jensen, M. (1983). Agency Problems and Residual Claims. The Journal of Law and Economics, 26, 327-349. https://doi.org/10.1086/467038

Fenn, G., \& Liang, N. (2001). Corporate Pay-Out Policy and Managerial Stock Incentives. Journal of Financial Economics, 60, 45-72. https://doi.org/10.1016/S0304-405X(01)00039-3

Fitza, M., \& Tihanyi, L. (2017). How Much Does Ownership Form Matter? Strategic Management Journal, 38, 2726-2743. https://doi.org/10.1002/smj.2671

Fleming, G., Heaney, R., \& McCosker, R. (2005). Agency Costs and Ownership Structure in Australia. Pacific-Basin Finance Journal, 13, 29-52.

https://doi.org/10.1016/j.pacfin.2004.04.001

Foroughi, M., \& Fooladi, M. (2011). Corporate Ownership Structure and Firm Performance: Evidence from Listed Firms in Iran. International Conference on Humanities, Society and Culture (ICHSC) Kuala Lumpur, 4-6 November 2011.

Foss, N., Klein, P., Lien, L., Zellweger, T., \& Zenger, T. (2020). Ownership Competence. Strategic Management Journal, 42, 302-328.

Fung, S., \& Tsai, S. (2012). Institutional Ownership and Corporate Investment Performance. Canadian Journal of Administrative Sciences/Revue Canadienne des Sciences de Administration, 29, 348-365. https://doi.org/10.1002/cjas.1232

García-Meca, E., \& Sánchez-Ballesta, J. (2009). Corporate Governance and Earnings Management: A Meta-Analysis. Corporate Governance: An International Review, 17, 594-610. https://doi.org/10.1111/j.1467-8683.2009.00753.x

Gillan, S. (2006). Recent Developments in Corporate Governance: An Overview. Journal of Corporate Finance, 12, 381-402. https://doi.org/10.1016/j.jcorpfin.2005.11.002

Gillan, S., \& Starks, L. (2000). Corporate Governance Proposals and Shareholder Activism: The Role of Institutional Investors. Journal of Financial Economics, 57, 275-305. https://doi.org/10.1016/S0304-405X(00)00058-1

Grant, G. (2003). The Evolution of Corporate Governance and Its Impact on Modern Corporate America. Management Decision, 41, 923-934.

https://doi.org/10.1108/00251740310495045

Grossman, S., \& Hart, O. (1980). Takeover Bids, the Free-Rider Problem, and the Theory of the Corporation. The Bell Journal of Economics, 11, 42-64.

https://doi.org/10.2307/3003400

Guercio, D., \& Hawkins, J. (1999). The Motivation and Impact of Pension Fund Activism. Journal of Financial Economics, 52, 293-340.

https://doi.org/10.1016/S0304-405X(99)00011-2 
Harryono, S. (2020). The Effect Analysis of Management Ownership Structure, Debt Policy and Risk on Financial Performance of Indonesian Manufacturing Companies. Journal of Economic, Accounting and Management Science, 1, 24-32.

Hartzell, J., \& Starks, L. (2003). Institutional Investors and Executive Compensation. The Journal of Finance, 58, 2351-2374. https://doi.org/10.1046/j.1540-6261.2003.00608.x

Hope, O., Langli, J., \& Thomas, W. (2012). Agency Conflicts and Auditing in Private Firms. Accounting, Organizations and Society, 37, 500-517. https://doi.org/10.1016/j.aos.2012.06.002

Iturralde, D., Maseda, A., \& Arosa, D. (2011). Insiders Ownership and Firm Performance: Empirical Evidence. International Research Journal of Finance and Economics, 67, 118-129.

Jeet, D., Bhatia, B. S., \& Sharma, R. K. (2020). Determinants of Ownership Pattern. Journal of Management Research and Analysis, 5, 146-153. https://doi.org/10.18231/2394-2770.2018.0023

Jensen, M., \& Meckling, W. (1976). Theory of the Firm: Managerial Behaviour, Agency Costs and Ownership Structure. Journal of Financial Economics, 3, 305-360. https://doi.org/10.1016/0304-405X(76)90026-X

Jensen, M. (1986). Agency Costs of Free Cash Flow, Corporate Finance, and Takeovers. The American Economic Review, 76, 323-329. http://www.jstor.org/stable/1818789

Jensen, M., \& Murphy, K. (1990). Performance Pay and Top-Management Incentives. Journal of Political Economy, 98, 225-264. https://doi.org/10.1086/261677

Karpoff, J., Malatesta, P., \& Walkling, R. (1996). Corporate Governance and Shareholder Initiatives: Empirical Evidence. Journal of Financial Economics, 42, 365-395. https://doi.org/10.1016/0304-405X(96)00883-5

Keasey, K., Short, H., \& Watson, R. (1994). Directors' Ownership and the Performance of Small and Medium Sized Firms in the U.K. Small Business Economics, 6, 225-236. https://doi.org/10.1007/BF01108290

Kole, R. S. (1996). Managerial Ownership and Firm Performance: Incentives or Rewards? Advances in Financial Economics, 2. https://ssrn.com/abstract $=7698$

La Porta, R., Lopez-de-Silanes, F., Shleifer, A., \& Vishny, R. (2000). Agency Problems and Dividend Policies around the World. The Journal of Finance, 55, 1-33. https://doi.org/10.1111/0022-1082.00199

Leland, H. (1998). Agency Costs, Risk Management, and Capital Structure. The Journal of Finance, 53, 1213-1243. https://doi.org/10.1111/0022-1082.00051

Li, J., Lam, K., Qian, G., \& Fang, Y. (2006). The Effects of Institutional Ownership on Corporate Governance and Performance: An Empirical Assessment in Hong Kong. Management International Review, 46, 259-276. https://doi.org/10.1007/s11575-006-0047-0

Loderer, C., \& Martin, K. (1997). Executive Stock Ownership and Performance Tracking Faint TRACES. Journal of Financial Economics, 45, 223-255. https://doi.org/10.1016/S0304-405X(97)00017-2

Masulis, R., Wang, C., \& Xie, F. (2009). Agency Problems at Dual-Class Companies. The Journal of Finance, 64, 1697-1727. https://doi.org/10.1111/j.1540-6261.2009.01477.x

Maug, E. (1998). Large Shareholders as Monitors: Is There a Trade-Off between Liquidity and Control? Journal of Finance, 53, 65-98. https://doi.org/10.1111/0022-1082.35053

McConnell, J., \& Servaes, H. (1995). Equity Ownership and the Two Faces of Debt. Journal of Financial Economics, 39, 131-157. 
https://doi.org/10.1016/0304-405X(95)00824-X

Mehran, H. (1995). Executive Compensation Structure, Ownership, and Firm Performance. Journal of Financial Economics, 38, 163-184. https://doi.org/10.1016/0304-405X(94)00809-F

Morck, R., Shleifer, A., \& Vishny, R. (1988). Management Ownership and Market Valuation. Journal of Financial Economics, 20, 293-315. https://doi.org/10.1016/0304-405X(88)90048-7

Nesbitt, S. (1994). Long-Term Rewards from Shareholder Activism: A Study of the "Calpers Effect”. Journal of Applied Corporate Finance, 6, 75-80. https://doi.org/10.1111/j.1745-6622.1994.tb00251.x

O’Callaghan, S., Ashton, J., \& Hodgkinson, L. (2018). Earnings Management and Managerial Ownership in Private Firms. Journal of Applied Accounting Research, 19, 648-668. https://doi.org/10.1108/JAAR-11-2017-0124

Shan, Y. (2019). Managerial Ownership, Board Independence and Firm Performance. Accounting Research Journal, 32, 203-220. https://doi.org/10.1108/ARJ-09-2017-0149

Shleifer, A., \& Vishny, R. (1986). Large Shareholders and Corporate Control. Journal of Political Economy, 94, 461-488. https://doi.org/10.1086/261385

Shleifer, A., \& Vishny, R. (1989). Management Entrenchment. Journal of Financial Economics, 25, 123-139. https://doi.org/10.1016/0304-405X(89)90099-8

Shleifer, A., \& Vishny, R. (1997). A Survey of Corporate Governance. The Journal of Finance, 52, 737-783. https://doi.org/10.1111/j.1540-6261.1997.tb04820.x

Slovin, M., \& Sushka, M. (1993). Ownership Concentration, Corporate Control Activity, and Firm Value: Evidence from the Death of Inside Blockholders. The Journal of Finance, 48, 1293-1321. https://doi.org/10.1111/j.1540-6261.1993.tb04755.x

Smith, A. (1776). An Inquiry into the Nature and Causes of the Wealth of Nations. Oxford Scholarly Editions Online. https://doi.org/10.1093/oseo/instance.00043218

Weir, C., Laing, D., \& McKnight, P. (2001). An Empirical Analysis of the Impact of Corporate Governance Mechanisms on the Performance of UK Firms. SSRN Electronic Journal. https://doi.org/10.2139/ssrn.286440 